\title{
HR Practices in Selected RMG Factories in Dhaka
}

\author{
Raju Mohammad Kamrul Alama, Silvia Akter ${ }^{*}$ \\ a Assistant Professor, Russian Peoples' Friendship University, Moscow, Russia. \\ b Senior Lecturer, East West University. \\ *Corresponding author's email address: silvia.akter@yahoo.com.
}

\section{A R T I C L E I N F O}

Received: 23-07-2016

Accepted: 16-08-2016

Available online: 29-09-2016

Keywords:

HR, Practice, RMG, Satisfaction.

JEL Classification:

J8, J28, M12,

\section{A B S T R A C T}

RMG sector is the largest foreign exchange earning sector of Bangladesh. This paper examines the HR practices of this sector and to help the policymakers to update the policy agenda in order for better supporting it to achieve the long-term goal. This is a pilot study on human resources practice of selected RMG factories in Dhaka. The HR officials were interviewed with a semi-structured questionnaire. The objective of this paper is to explore the HR practices of RMG sector in Dhaka. The results showed that RMG factories now trying to maintain the best practices to create a good image as they now become the part of global supply. The paper suggested that global labor standards, good HR practice and professional management are required for the smooth operation of this sector.

This is an open access article under the terms of the Creative Commons Attribution License 4.0, which allows use, distribution and reproduction in any medium, provided the original work is properly cited.

DOI: http://dx.doi.org/10.18533/job.v1i4.47

ISSN 2380-4041(Print), ISSN 2380-405X(Online)

\subsection{Introduction}

With around USD 15 billion in export value in calendar year 2010, the RMG industry is currently Bangladesh's most important industry sector (13 percent share of GDP and total export share of over 75 percent). With 12 percent average annual growth rates, clothing exports are the key driving force behind GDP development (7 percent CAGR from 1995 to 2010).With a current 5,000 RMG factories employing about 3.6 million workers from a total workforce of 74 million, Bangladesh is clearly ahead of Southeast Asian RMG suppliers in terms of capacity offered (McKinsey, 2011).

The export-oriented readymade garments (RMG) industry of Bangladesh has witnessed remarkable growth since its inception in the late 1970s. RMG industry of Bangladesh is mainly export oriented and a main source of foreign exchange for the last 25 years. The historical development of RMG sector was well grasped in the writing of Mahfuz (2013). In his own words: 'In the 1980s, there were only 50 factories employing only a few thousand people. Currently, there are 4490 manufacturing units. The RMG sector contributes around 76 percent to the total export earnings. In 2007 it earned \$9.35 billion. This sector also contributes around 13 percent to the GDP, which was only around 3 percent in 1991. Of the estimated 4.2 million people employed in this sector, about 50 percent of them are women from rural areas. In 2000, the industry consisting of some 3000 factories employed directly more than 1.5 million workers of whom almost $80 \%$ were female. USA is the largest importer of Bangladeshi RMG products, followed by Germany, UK, France and other E.U countries". Retrieved on(March 21,2016) from: http://textilelearner.blogspot.com/2013/10/condition-of-ready-madegarment-rmg_9785.html\#ixzz43WmnuYwD(on. Mahfuz (2013) also added that "Readymade garment (RMG) is the key export item and a main source of foreign exchange for the last 25 years. Bangladesh textile garments sector has been expanded in a vigorous way and maintained its maturity by holding 2nd position globally with 
5\% market share in Readymade Garments production and export in 2012. During the Fiscal Year (2011-12) our total export volume was USD 24.23 billion. Out of the total export, export from the RMG sector was USD 19.08 billion which is 78.7\%. Global market size export of RMG (Woven \& Knit) is US\$ 400 billion. Bangladesh share in the global market is about $5 \%$. This mere $5 \%$ share alone is literally strong to indicate that there is a great opportunity of expansion. Retrieved on (March, 2016) from:http://textilelearner.blogspot.com/2013/10/condition-of-ready-made-

garmentrmg_9785.html\#ixzz43WoJsZLu. Given the export growth rate and importance of this sector in the economy, this paper examines the one of most crucial part of its success, the system of human resource management of this sector. Its' found that HR practices in this sector is not formalized and not discussed much in the literature (Majumder and Begum (2000): Absar (2001). Considering this gap in literature, this paper explores the human resources policies and practices of selected RM factories of Bangladesh. In doing so, an exploratory research with questionnaire was carried out and the results showed that the core HR practices were more or less absent in the surveyed factories. This finding sends a signal to the government to monitor and regulate the industry more strictly.

\subsection{Literature review}

Many research shows that company mainly focus on HR planning. As a result they give less concentration on HR practice. HR manages high level to low level employees through connecting a bridge. HR professionals use manpower planning and forecasting techniques. HR manager always search job that is perfectly done by employees. As a result, HR manager should recruit perfect employees for perfect position, but they also need to concern about the satisfaction of existing employees. The scenario of the RMG sector in respect to HR practice, working condition, job satisfaction revealed in may past research. For example, in an early research PaulMajumder and Begum (2000) elaborated the conditions of RMG sector prevailing in (1990; 1993 and 1997). They found that male and female workers of garment industry work about 12 hours a day, leave facilities and weekly holiday were not available much, although the workers were paid for overtime work on weekly holiday, no alternative holidays were given to these workers, career progression is halted, factories are overcrowded, congested and poorly ventilated, air pollution is rampant, lack of fire protection measures, poor toilet, no lunch room, lack of pure drinking water, employees are not entitled to any fringe benefits including accommodation allowance, health care, emergency funds and transportation.

Absar (2001) in her study mentioned that Bangladesh has the cheapest unit of labor cost in South Asia. It costs only 11 cents to manufacture a shirt in Bangladesh whereas it costs 79 cents in Srilanka and 26 in India. Clearly, the comparative advantage of Bangladesh in this case lies in having the cheapest unit labor cost. The author also mentioned that workers of garment factories in Bangladesh are asked to work whole months at a time without a single day off. After ten years, Rogers (2010) in his writing also mentioned that Bangladeshi garment workers are the lowest paid garment workers in the world. Although their minimum wage was supposed to have risen to about $\$ 40$ a month in November 2010, many garment factory owners are still paying the old minimum wage of $\$ 24$ a month.

Considering the above background this research focuses on the presents HR conditions of RMG sector in Bangladesh with special emphasis on employing condition and HR practices, for example performance appraisal, job satisfaction etc,. Evaluation of employees' performance is a common practice in today's business organization. It has long been recognized that performance appraisal plays pivotal role in organization(Borman, 1979; Landy and Farr, 1980; Saal, Downey and Lahey, 1980).Employee performance appraisal is subjects of great interest in most organizations (Armstrong, 1998; Bratton and Gold, 1999).One of the reasons behind this is performance appraisal decisions have effects and consequences on worker's compensation and recognition (Bartol and Locke, 2000; Millward et al,. 2000; Perry, 1995).

The aim of the research is to see the state of human resource management in RMG sector.. The key research objectives are to evaluate the recruitment, the job analysis, training and development, performance evaluation and compensation system of the sector.

\subsection{Methodology}

This is an exploratory research. The sample size was fifty. The sapless were selected following the convenience sampling technique. The respondents of the survey were the administrative staffs of the readymade garments factories. A structured questionnaire was used to collect the data. The question item were developed on the basis of the core human resource functions of any company. 


\subsection{Findings \& Analysis}

According to the results, job description and job specification are well maintained. $43 \%$ of the companies opted for moderately structured, $36 \%$ chosen well structured and only $21 \%$ of companies have chosen very structured job description and specification. The recruitment process of the workers in the industry is primarily informal and follows internal recruitment. 50\% employees are being selected by internal recruitment, $36 \%$ are walk-in and rest $14 \%$ has local referrals but mostly they follow internal recruitment process. For recruiting new workers apart from walk in interview follow some methods such as verbal, written test or interview and according to the survey $64 \%$ respondents confirmed that some sorts of selection test they use occasionally.

Almost none of the companies provide any training and development opportunities for the workers. Training is a must for making people effective and efficient and also to increase the level of awareness about safety, hygiene maintenance, and health issues. Only 5\% respondents confirmed that they have training facilities for their employees though some reported that they have got training initiative for the managerial people. Training for supervisor's workers is common (70\%) because workers development depends to a great extent on learning on the job. General workers are recruited as non-skilled and learn the work technique under close supervision of the floor supervisors. So, the companies use the supervisor technique to develop the workers and ensure quality. Skill training institute for garments workers is rare and as a result, general workers in many cases feel frustrated. $86 \%$ of the respondents reported that there is no training or institutes for enhancing their knowledge and capability.

Performance evaluation is primarily carried out through rating scales methods and depending on supervisor's report. Evaluating employee performance is crucial for employee retention and development. Generally, most of the organization follows the supervisor's report for evaluating employee performance. Performance evaluation is the basis for employee reward decision and proper reward is important for employee satisfaction and organizational success. Evaluation most of the time depends on supervisors reports and observation.

For compensation system most companies used the governments rules and regulations, some bonus system also present there. Reward system mainly follows monetary reward system and this will help them not only financially, also mentally by motivating them. $57 \%$ respondents observed that the compensation system is well structured and $43 \%$ opined that it's very moderate to structure. Majority (50\%) of the companies reported that they follow performance based compensation package for workers and employees and(43\%) follow industry based compensation system. Monetary reward is the most usual form of compensation. $86 \%$ of the respondents follow the monetary reward system. Interestingly, there is no discrimination among the women and men workers in terms of compensation structure, leave policy and HR issues. However, managers of some companies state that middle and upper level positions are mostly filled up by males.

Apart from the salary some benefits like festival bonus, performance bonus, health insurance, gratuity and provident fund also given for the betterment of the workers. Festival bonus and performance bonus offered by almost all the organizations.

Technical competency and seniority level are the two variables used by the workers for job progression. Supervisors' report also contains technical expertise of the employees. $90 \%$ of the respondents reported that supervisors' are asked to provide adequate information about the employee's technical skill. Most of the respondents reported that they maintain fairness and justice, while considering the promotion decisions. However, employees past record, supervisors report, behavior, disciplinary records are all considered before making final decisions.

Companies are very much careful about the workers right, health and safety. The management maintains good relationship with the employees. Majority $55 \%$ of the companies maintain good relation with the employee, $21 \%$ have excellent relation and rest $24 \%$ of the companies maintains moderate relationship. Majority of the companies follow the Bangladesh labor law in respect to workers rights, facilities and safety. According to Bangladesh labor code 2006, all workers have the right to know about all issues related with their safety, rights, freedom, responsibilities and company have to maintain the labor law properly.

None of the companies surveyed faced any problems in case of labor outrage in the previous 5 years. Majority the respondents reported that management-employee relationship is very positive in their organization though some problems occur. However, these problems occur due to misunderstanding between supervisor and worker, personal issues, conflicts among the workers etc. It was also revealed in the interview RMG companies now a day become very much careful about labor relation, dealing with media, and social auditors. Since international buyers are very much sensitive about the labor standards, they also look for self-regulation so that 
they do not get involved with any controversies. The surveyed firms try to maintain the best practices to avoid any disputes and controversy.

\subsection{Conclusions}

Best HR policies and practices should be maintained and implemented in RMG sector. RMG factories have become the part of a global supply chain so these firms have to maintain the global standard in respect to work environment, employee's responsibilities, relationship with the management and workers, proper maintenance of rules and regulations, and health, environment and safety. HR practices always supposedly contribute to an improved bottom line performance are generally perceived as "good" for "workers" like, employee security, training and development, information and consultation, higher levels of pay and work-life balance, which looks like an attractive scenario for employees and workers alike. Most of the RMG workers are illiterate in Bangladesh. As a result they are not concern about human rights, working condition and labor standards. Global garments buyer need these assurance. So, HR practices in RMG sector should try to maintain proper HR practices in the sector to ensure job satisfaction among the employees. Job satisfaction as has been defined by Locke (1976) as 'a pleasurable or positive emotional state resulting from the appraisal of one's job or job experiences", should be maintained by the RMG sector. Its suggested that the stakeholders of this sector e.g.. government, BGMEA, NGO's, workers federation should emphasize on more on development of technical expertise of the workers. Establishment of more training centers, encouraging on the job training, intensive monitoring of health, safety and security issues are found to be crucial for the sustained growth of the sector.

\section{References}

Absar, S. S. (2001). Problems Surrounding Wages: the Ready Made Garment Sector in Bangladesh. Labour and Management in Development Journal, 2(7), ISSN: 1443-6698, Asia Pacific Press-2001managers of RMG sector should revised HR planning and practice.

Armstrong, M. (1998). Managing people: A Practical Guide for Line Managers, London: Kogan Page.

Bangladesh's ready-made garments landscape: The challenge of growth. McKinsey, 2011.

Bartol, K. M. and Locke, E. A. (2000). Incentives and Motivation. In Sara L. Rynes and Barry Gerhart (Eds.), Compensation in Organizations: Current Research andPractice (104-147). San Francisco: Jossey Bass.

Borman, W. C. (1979). Format and training effects on rating accuracy and rater errors. Journal of Applied Psychology, 64: 412-421. http://dx.doi.org/10.1037/0021-9010.64.4.410

Bratton,J. and Gold,J. (1999). Human Resource Management: Theory and Practice(2nd Ed)London: Macmillan Business. http://dx.doi.org/10.1007/978-1-349-27325-6

Landy, F. J. and Farr, J. L. (1980). Performance Rating. Psychological Bulletin, 87:72-107. http://dx.doi.org/10.1037/0033-2909.87.1.72

Locke, E.A. 1976. The Nature and Causes of Job Satisfaction. Chicago IL: Rand McNally.

Mahfuz, M (2013) Conditions of RMG Sector of Bangladesh http://textilelearner.blogspot.com /2013/10/condition-of-ready-made-garment-rmg_9785.html\#ixzz43X6qo5I2.

Millward, N., Bryson, A.and Forth,J. (2000). All Change at Work? British employment relations 1980-1998, as portrayed by the Workplace Industrial Relations Survey, London: Routledge.

Perry,J. (1995). Compensation, Merit pay and Motivation, in Hays, S.W. and Kearney, R.C. (Eds) Public Personnel Administration: Problems and Prospects, Prentice Hall, Englewood Cliffs, NJ

Saal, F. E., Downey, R. G. and Lahey, M. A. (1980). Rating the ratings: assessing the psychometric quality of rating data. Psychological Bulletin, 88: 413-428. http://dx.doi.org/10.1037/0033-2909.88.2.413 